\title{
Inflammation in children with chronic kidney disease linked to gut dysbiosis and metabolite imbalance
}

Johannes Holle ${ }^{1,2,3^{*}}$, Hendrik Bartolomaeus ${ }^{2,3,4,5}$, Ulrike Löber ${ }^{2,3,4,6}$, Felix Behrens ${ }^{1,3,6,7}$, Theda U. P. Bartolomaeus ${ }^{2,3,4,6}$, Harithaa Anandakumar ${ }^{2,4,5}$, Moritz I. Wimmer ${ }^{2,3,4,5,8}$, Dai Long $\mathrm{Vu}^{4,9}$, Mathias Kuhring ${ }^{4,6,10}$, Andras Maifeld ${ }^{2}$, Sabrina Geisberger ${ }^{4,11}$, Stefan Kempa ${ }^{4,11}$, Philip Bufler $^{1}$, Uwe Querfeld ${ }^{1}$, Stefanie Kitschke ${ }^{1}$, Denise Engler ${ }^{1}$, Leonard D. Kuhrt ${ }^{1,4}$, Oliver Drechsel ${ }^{12}$, Kai-Uwe Eckardt ${ }^{5}$, Sofia K. Forslund ${ }^{2,3,4,6,13}$, Andrea Thürmer ${ }^{14}$, Victoria McParland ${ }^{2,4}$, Jennifer A. Kirwan ${ }^{4,9}$, Nicola Wilck $^{2,3,5,6 \#^{*}}$, Dominik Müller ${ }^{1 \#^{*}}$

11 Department of Pediatric Gastroenterology, Nephrology and Metabolic Diseases, Charité 2 Universitätsmedizin Berlin, 13353 Berlin, Germany

32 Experimental and Clinical Research Center (ECRC), a cooperation of Charité 4 Universitätsmedizin Berlin and Max Delbruck Center for Molecular Medicine (MDC), 13125

5 Berlin, Germany

63 DZHK (German Centre for Cardiovascular Research), partner site Berlin, 13316 Berlin, 7 Germany.

84 Max Delbrück Center for Molecular Medicine in the Helmholtz Association (MDC), 13125 9 Berlin, Germany

5 Department of Nephrology and Medical Intensive Care Medicine, Charité -

11 Universitätsmedizin Berlin, 13353 Berlin, Germany

126 Charité - Universitätsmedizin Berlin and Berlin Institute of Health, 10117 Berlin, Germany

8 Department of Internal Medicine IV, Division of Endocrinology, Diabetology and Nephrology, University Hospital of Tübingen, 72076 Tübingen, Germany 
medRxiv preprint doi: https://doi.org/10.1101/2022.01.21.22269663; this version posted January 23, 2022. The copyright holder for this preprint

(which was not certified by peer review) is the author/funder, who has granted medRxiv a license to display the preprint in perpetuity.

All rights reserved. No reuse allowed without permission.

12 MF1 Bioinformatics, Robert Koch Institute, 13353 Berlin, Germany

21

13 European Molecular Biology Laboratory, 69117 Heidelberg, Germany

14 MF2 Genome Sequencing, Robert Koch Institute, 13353 Berlin, Germany

22

\# Authors contributed equally to this publication

${ }^{*}$ corresponding authors

\section{Abstract}

26 Chronic kidney disease (CKD) is characterized by a sustained pro-inflammatory response.

27 The underlying mechanisms are incompletely understood, but may be linked to gut dysbiosis. Dysbiosis has been described in adults with CKD; however, comorbidities limit CKD-specific conclusions. We analyzed the fecal microbiome, metabolites and immune phenotypes in children at three different CKD stages (G3-G4, G5 (hemodialysis), after kidney transplantation) and healthy controls. Serum TNF-a and SCD14 were stage-dependently elevated, indicating inflammation and gut barrier dysfunction. We observed microbiome alterations in CKD, including a diminished production of short-chain fatty acids. Bacterial tryptophan metabolites were increased in CKD. CKD serum activated the aryl hydrocarbon receptor and stimulated TNF-a production by monocytes, corresponding to a shift towards intermediate/non-classical monocytes. Unsupervised $\mathrm{T}$ cell analysis revealed pro-

37 inflammatory shifts in MAIT and Treg cells. Thus, gut barrier dysfunction and microbial metabolites exacerbate inflammation and may therefore contribute to the increased cardiovascular burden in CKD. 
medRxiv preprint doi: https://doi.org/10.1101/2022.01.21.22269663; this version posted January 23, 2022. The copyright holder for this preprint (which was not certified by peer review) is the author/funder, who has granted medRxiv a license to display the preprint in perpetuity.

All rights reserved. No reuse allowed without permission.

\section{Introduction}

Despite ongoing efforts to improve the treatment of patients with chronic kidney disease (CKD), they still suffer from high morbidity and mortality, primarily due to cardiovascular diseases $(C V D)^{1}$. Besides known risk factors such as arterial hypertension and proteinuria ${ }^{1}$, recent studies suggest a crucial role for microbially produced metabolites in promoting inflammation ${ }^{2,3}$ and, as a consequence, progression of $C K D$ and $C V D^{1,3,4}$.

There is longstanding evidence showing that an imbalance in the bacterial community residing in the gut with changes in its functional composition, termed dysbiosis, is common in adult patients with $C K D^{5,6}$. Beyond the influence of CKD, a variety of other factors, such influence of diet and drugs, are suspected to contribute to dysbiosis in $\mathrm{CKD}^{6}$. These changes are paralleled by an altered bacterial metabolism of nutrients and a systemic accumulation of uremic toxins of bacterial origin, such as indoxyl sulfate $(\mathrm{IxS})^{7}$. It is conceivable that dysbiosis and metabolite dysbalance aggravate systemic inflammation, which could provide a potential mechanism for the high rate of premature cardiovascular events ${ }^{3}$.

Recently, we demonstrated a positive association between IxS and early cardiovascular disease in children with $\mathrm{CKD}^{8}$. In contrast to adults with $\mathrm{CKD}$, children are less affected by risk factors such as diabetes, obesity, and metabolic syndrome, but mainly suffer from congenital anomalies of the kidney and urinary tract $(\text { CAKUT })^{9}$. Thus, a pediatric cohort offers the unique opportunity to analyze the impact of CKD on microbiota-host interaction more specifically.

Our cohort includes pediatric CKD patients, those on hemodialysis (HD), patients after kidney transplantation (KT) and age-matched healthy controls ( $\mathrm{HC})$. We show, for the first time a CKD specific dataset of gut microbiome composition, altered microbial metabolism of nutrients, and the corresponding impact on inflammation and immune cell dysregulation in children suffering from CKD. We connect the bacterial metabolite dysbalance to a proinflammatory immune cell signature, emphasizing the importance of the microbiota for chronic inflammation in CKD. The fact that these dysbiosis-driven immunological changes 
medRxiv preprint doi: https://doi.org/10.1101/2022.01.21.22269663; this version posted January 23, 2022. The copyright holder for this preprint

(which was not certified by peer review) is the author/funder, who has granted medRxiv a license to display the preprint in perpetuity.

All rights reserved. No reuse allowed without permission.

67 are already detectable in children with CKD highlights the potential of microbiota-targeted

68 therapies to improve prognosis of CKD patients across all ages. 
medRxiv preprint doi: https://doi.org/10.1101/2022.01.21.22269663; this version posted January 23, 2022. The copyright holder for this preprint (which was not certified by peer review) is the author/funder, who has granted medRxiv a license to display the preprint in perpetuity.

All rights reserved. No reuse allowed without permission.

69

70

71

\section{Patients and methods}

\section{Study population}

In this cross-sectional study, we recruited patients from the Department of Pediatric Gastroenterology, Nephrology, and Metabolic Diseases at Charité University hospital in Berlin, Germany, between February 2018 and June 2018. Written informed consent was obtained from all participants and/or their parents prior to study entry. The study was approved by the local Ethical Review Board (EA2/162/17). All procedures performed were in accordance with the ethical standards of the institutional and national research committees and the 1964 Helsinki declaration and its later amendments or comparable standards.

Patients (age 3-18 years) were enrolled in the following groups:

- CKD group: CKD stage G3-G4, estimated GFR (eGFR) 15-60 ml/min*1.73m²

- HD group: CKD stage G5D, patients on maintenance hemodialysis, enrolled earliest four weeks after initiation of HD

- KT group: patients after successful KT, earliest four weeks after KT, without a history of rejection or chronic graft failure, eGFR $>60 \mathrm{ml} / \mathrm{min}^{*} 1.73 \mathrm{~m}^{2}$

- HC group: normal kidney function, treated at the hospital for reasons other than kidney disease

We excluded patients with a body weight below $15 \mathrm{~kg}$, acute or chronic inflammatory diseases, fever, diabetes, chronic liver disease, inflammatory bowel disease, or other gastrointestinal disorders (constipation, diarrhea, short bowel syndrome). Patients with antibiotic prophylaxis or treatment within the four weeks prior to recruitment were excluded.

\section{Statistical analysis}

Microbiome and metabolome analysis: Alpha diversities of microbial communities (Shannon diversity as computed by RTK, defined at the OTU level) were compared between groups using Kruskal-Wallis (KW) test. Beta diversity was assessed using Euclidean (metabolome) 
medRxiv preprint doi: https://doi.org/10.1101/2022.01.21.22269663; this version posted January 23, 2022. The copyright holder for this preprint (which was not certified by peer review) is the author/funder, who has granted medRxiv a license to display the preprint in perpetuity.

All rights reserved. No reuse allowed without permission.

and Canberra (microbiome) dissimilarity index between samples computed using vegan package v2.5-7. Principal Coordinates Analysis (PCoA) was performed using the vegan package v2.5-7 (employing Euclidean and Canberra distance metrics as above). PERMANOVA was performed using the adonis function from the vegan package v2.5-7. We estimate differential abundance on phylum and genus level between groups using the package DESeq2 v1.30.1. The DESeq2 pipeline uses negative binomial distribution models to test for differential abundance between testing conditions. We ran the pipeline with normalized counts under default settings. $P$ values were adjusted according to BenjaminiHochberg $(\mathrm{BH})$ false discovery rates (FDR) correction. A q-value of $<0.1$ was considered statistical significant.

For each pair of patient groups, features from the TRP analysis were compared using twosided Mann-Whitney-U (MWU) tests with effect sizes calculated as Cliff's delta metric per the R ordom package v3.1. Effect sizes were taken as Spearman's rho. All significance estimates were adjusted for multiple tests using BH-FDR correction. To assess the effect of patient groups on tryptophan pathway metabolites (concentrations), multifactor ANOVAs were calculated per metabolite to account for multiple groups as well as potential confounders (including age, sex, ethnical background, underlying disease category, BMI, and eGFR).

The co-abundance network of host, microbiome and metabolome features was calculated from the dataset as a whole by assessing pairwise Spearman correlations and adjusted for multiple testing using $\mathrm{BH}-\mathrm{FDR}$ correction as implemented in the $\mathrm{R}$ psych package v1.9.12. Edges for which absolute rho $>0.3$ and $Q<0.1$ were visualized using the iGraph R package. Correlations were separately also assessed stratifying for group effects using the $\mathrm{R}$ coin package v1.3.1.

Flow cytometry: For all FlowSOM clusters we computed log2 fold changes (fc). Cluster log2fc were visualized using ggplot2 package v3.3.5. For all subpopulations of Treg and MAIT cells, we calculated log2fc and assessed statistical significance using two-sided MWU-tests 
medRxiv preprint doi: https://doi.org/10.1101/2022.01.21.22269663; this version posted January 23, 2022. The copyright holder for this preprint

(which was not certified by peer review) is the author/funder, who has granted medRxiv a license to display the preprint in perpetuity.

All rights reserved. No reuse allowed without permission.

121 between HD and HC with BH-FDR correction. A q-value of $<0.1$ was considered statistically

122 significant. Data was visualized using the EnhancedVolcano package v4.1.2.

123 Boxplots: Analysis and graphical representation was performed in GraphPad Prism 9.3.1

124 (GraphPad Software, CA, USA). Boxplots depict median and interquartile range with

125 whiskers from $\min$ to max. Overlaid data points represent individual patients or

126 measurements. Normality was assessed using Q-Q-plots and Shapiro-Wilk test. For more

127 than two groups we performed one-way ANOVA with Tukey post-hoc test or KW test with

128 Dunn's post-hoc test, as appropriate. For two group comparisons, we performed two-sided

129 Student's t-test or two-sided MWU test, as appropriate.

130 For all analysis $P$ value of $<0.05$ (unadjusted or adjusted, as appropriate) and a $Q$ value of $131<0.1$ was considered statistically significant. 
medRxiv preprint doi: https://doi.org/10.1101/2022.01.21.22269663; this version posted January 23, 2022. The copyright holder for this preprint (which was not certified by peer review) is the author/funder, who has granted medRxiv a license to display the preprint in perpetuity.

All rights reserved. No reuse allowed without permission.

\section{Results}

\section{Childhood CKD marked by arterial hypertension, inflammation and leaky gut}

134 Ten healthy individuals $(\mathrm{HC})$ and 38 patients were enrolled in the study (Supplementary Figure 1). Baseline characteristics are given in Table 1. Participant mean age was $10.6 \pm 3.8$ years with 21 females and 27 males. CAKUT was the most prevalent underlying disease category. Patients treated with HD had a median time on dialysis of six months (range $3-29$ months) with a median residual diuresis of $50 \mathrm{ml}$ per day (range $0-1800 \mathrm{ml}$ per day) and a mean Kt/Vof $1.56 \pm 0.27$ (SD), indicating adequacy of HD treatment. Patients after KT had a stable graft function with a mean eGFR of $78.8 \pm 19.4 \mathrm{ml} / \mathrm{min}^{*} 1.73 \mathrm{~m}^{2}$. The median time from transplantation was 48 months (range $10-125$ months).

Both the CKD group (CKD stage G3-G4) and the HD group (CKD stage G5D) were hypertensive (83\% and $91 \%$, respectively) and received antihypertensive treatment $(1.8 \pm$ 1.5 antihypertensive drugs in the CKD group and $2.4 \pm 1.9$ drugs in the HD group, Figure 1a, Table 1). Six HD patients (55\%) exhibited hypertensive blood pressures at the time of study enrolment despite treatment (Table 1). In the HD and CKD groups serum levels of the proinflammatory cytokine TNF-a were stage-dependently increased and significantly higher than in the HC group (Figure 1b), while differences in the levels of other pro- and antiinflammatory cytokines did not reach significance (Supplementary Table 2). Notably, TNF-a was also significantly elevated in patients after KT compared to HC (Figure 1b). We next investigated serum levels of the tight junction protein zonulin-1 (Zo-1) and the

152 lipopolysaccharide (LPS) binding protein soluble CD14 (sCD14), which were elevated in

153 CKD and HD compared to control and KT (Figure 1c), indicating stage-dependent intestinal barrier dysfunction and CKD-associated endotoxemia. Thus, in the absence of classical cardiovascular risk factors other than hypertension, CKD in children is characterized by elevated serum markers of inflammation and leaky gut. 
medRxiv preprint doi: https://doi.org/10.1101/2022.01.21.22269663; this version posted January 23, 2022. The copyright holder for this preprint (which was not certified by peer review) is the author/funder, who has granted medRxiv a license to display the preprint in perpetuity.

All rights reserved. No reuse allowed without permission.

158 Since intestinal barrier dysfunction may be associated with dysbiosis, we next sought to 159 analyze the taxonomic composition of the gut microbiome. We performed $16 \mathrm{~S}$ amplicon 160 sequencing in $n=32$ study participants with available fecal samples. We observed a high 161 interindividual compositional variability at phylum level (Figure 2a). Microbiome richness and diversity, as measured by the Shannon diversity index, tended to be lower in CKD and HD patients compared to $\mathrm{HC}$ but this difference did not reach statistical significance (Figure 2b). However, analysis of beta diversity (Canberra distance) indicated significant differences in microbiome composition between groups, with CKD and HD groups separating most clearly from the $\mathrm{HC}$ (Figure $2 \mathrm{c}, \mathrm{p}=0.01$ ). Analysis of bacterial composition on genus level revealed significant alterations predominantly in HD patients (Figure $2 \mathrm{~d}$ ). First, relative abundances of Firmicutes and Actinobacteria such as Fusicatenibacter (belonging to the family of (Bifidobacteriaceae) were significantly diminished in HD patients compared to HC. Second, we found an increase in relative abundance of Proteobacteria and Bacteroidetes, such as Citrobacter (Enterobacteriaceae), Parasutterella (Parasutterellaceae), and several genera of

173 Bacteroides (Bacteroidaceae) in CKD and HD groups compared to HC and KT. Taken together, the taxonomic microbiome changes in CKD are stage-dependent, most pronounced in the HD group and less pronounced after KT. The abundance of proteolytic bacteria (such as Citrobacter) increases in CKD whereas saccharolytic bacteria (such as Bifidobacterium) decrease.

\section{CKD stage-dependent dysbalance of bacterial metabolites}

To investigate the functional effects of the observed alterations in microbiome composition on host physiology, we focused a plasma metabolite analysis on tryptophan (TRP) metabolites and SCFA. Dietary TRP is a substrate for both cellular metabolism and bacterial proteolytic fermentation and the latter is a source of microbial produced uremic toxins, such as IXS. We found significant differences in the abundance of TRP metabolites in CKD and HD compared to the HC and KT groups (Figure 3a). CKD and HD patients showed a large- 
medRxiv preprint doi: https://doi.org/10.1101/2022.01.21.22269663; this version posted January 23, 2022. The copyright holder for this preprint (which was not certified by peer review) is the author/funder, who has granted medRxiv a license to display the preprint in perpetuity.

All rights reserved. No reuse allowed without permission.

202

scale shift from TRP to its indole and kynurenine (KYN) metabolites, which was predominantly driven by an increase of IxS (Figure 3b). We found a significant decrease in plasma TRP concentrations in patients with CKD and HD, while IxS and 5 KYN metabolites (KYN, kynurenic acid (KA), 3-OH-kynurenine $(3 \mathrm{OH}-\mathrm{KYN})$, anthranilic acid $(\mathrm{AA})$, xanthurenic acid (XA)) were significantly elevated (Figure 3c). Interestingly, patients after KT had similar metabolite levels compared to $\mathrm{HC}$ with the exception of $\mathrm{KYN}$ and $3 \mathrm{OH}-\mathrm{KYN}$ (Figure 3c). Individual values of TRP, IxS and, KA are shown across the different groups in Figure $3 d-f$. The activation of the cellular KYN pathway is also indicated by the ratio of KYN to TRP, which was significantly elevated in CKD and HD (Figure 3g). A multivariate ANOVA showed that age, sex, ethnic background, underlying disease category, and BMI did not confound metabolite levels. Only group and eGFR had an impact on several of the compounds (Supplementary Table 3), confirming their accumulation with declining eGFR. Because indole and KYN metabolites have been shown to activate the aryl hydrocarbon receptor $(\mathrm{AhR})$, a transcription factor and potential mediator of microbiome-host interactions, we measured the AhR activating potential of serum from the HD and HC group in vitro using a cell-based reporter assay. Serum from HD patients induced a significantly higher AhR activity as compared to HC (Figure 3h). Similarly, IxS activates the AhR in a dose-dependent manner (Supplementary Figure 2).

To further functionally validate our findings of decreased abundancies of saccharolytic microbes, we measured the abundance of a central enzyme for bacterial SCFA production by qPCR of fecal DNA using degenerate primers. The abundancy of the butyrate gene was lower in the DNA extracted from fecal samples of HD patients relative to the other patient groups (Supplementary Figure 3a). Next, we measured SCFA in serum. The SCFA propionate and isobutyrate were reduced in patients with $\mathrm{HD}$ compared to $\mathrm{HC}$, while serum concentrations of butyrate did no differ significantly between groups (Supplementary Figure 3b). Thus, we were able to show on a functional level that the observed stage-dependent microbiome changes have an impact on the production and abundance of bacterial metabolites. 
medRxiv preprint doi: https://doi.org/10.1101/2022.01.21.22269663; this version posted January 23, 2022. The copyright holder for this preprint (which was not certified by peer review) is the author/funder, who has granted medRxiv a license to display the preprint in perpetuity.

All rights reserved. No reuse allowed without permission.

213 In order to comprehensively visualize the relationship of clinical, microbial and metabolomic

214 parameters, we performed a correlation network analysis (Figure 4). Here, TNF-a correlated

215 positively with SCD14, Proteobacteria, IXS, several KYN metabolites and biomarkers of

216 kidney function (Figure 4a, positive correlations). Conversely, the SCFA propionate and

217 isobutyrate correlated inversely with TNF-a, IXS, KYN metabolites and kidney function

218 (Figure 4b, negative correlations). Firmicutes correlated positively with microbial diversity,

219 butyrate and I3PA. These associations support our assumption of kidney function as a catalyst of gut bacteria-driven inflammation.

Monocyte subsets contribute to the pro-inflammatory phenotype in CKD

The AhR is expressed in various immune cells including myeloid cells and is known to modulate their function ${ }^{10}$. It is assumed that the accumulation of AhR ligands in CKD leads to immune cell activation. We therefore isolated monocytes from healthy donors and incubated them with serum from HD patients or HC. Monocytes incubated with HD serum showed a significantly higher TNF-a production (Figure 5a). Similarly, incubation of isolated monocytes with IXS dose-dependently increased TNF-a production which could be reversed by coincubation with the synthetic AhR-antagonist $\mathrm{CH}-223191$, highlighting the importance of AhR-mediated immune activation in CKD (Figure 5a).

In order to get a broader overview of changes in relevant immune cell populations in CKD, we re-collected peripheral blood mononuclear cells (PBMC) from seven $\mathrm{HC}$ and six $\mathrm{HD}$ patients for immunophenotyping using flow cytometry. Unsupervised FlowSOM analysis ${ }^{11}$ of our monocyte and dendritic cell targeting flow panel (see Supplementary table 1, supplementary figure 4, Figure 5b), showed phenotypic alterations of monocytes (cluster 3 , Figure 5c) being decreased (Figure 5d) and dendritic cell (cluster 7, Figure 5c) being increased (Figure 5d) in HD patients. Using classical hierarchical gating, we observed similar abundances of total monocytes (identified by HLA-DR, CD14, and CD16 as described $\mathrm{in}^{12}$ ), but a significant shift from classical (CD14+CD16-) towards non-classical (CD14-CD16+) and intermediate (CD14+CD16+) monocytes in HD (Figure 5e), the latter two being known for 
medRxiv preprint doi: https://doi.org/10.1101/2022.01.21.22269663; this version posted January 23, 2022. The copyright holder for this preprint (which was not certified by peer review) is the author/funder, who has granted medRxiv a license to display the preprint in perpetuity.

All rights reserved. No reuse allowed without permission.

240 their potent production of TNF- $a^{13}$. Hierarchical gating within the dendritic cell population

241 revealed no significant differences of dendritic cell types (Supplementary Figure 5). Thus, HD

242 patients are characterized by alterations within myeloid cells, showing a shift from classical to

243 pro-inflammatory intermediate and non-classical monocytes.

Pro-inflammatory T cell subsets in CKD

245 Since SCFA and TRP metabolites are known to modulate T cell differentiation and function, 246 we expanded our flow cytometry to include analysis of T cells (Supplementary table 1, T 247 surface panel, supplementary figure 4). We again performed FlowSOM analysis using 8 clusters (Figure 6a). Mucosal associated invariant T (MAIT) cells and a subpopulation of regulatory T cells (Treg) (Clusters 6 and 3, respectively, Figure 6b) exhibited the largest effects between HD and HC patients (Figure 6c). We confirmed this finding by classical hierarchical gating, with circulating MAIT cells (CD3+CD161+TCRVa7.2+) being decreased in HD (Supplementary Figure 6a). Next, we performed a more detailed analysis of MAIT cell subpopulations. After adjusting for multiple testing, we found a decrease of CD4-CD8- MAIT cells, while CD4+CD8- and CD4+CD8+ cells were enriched in HD (Figure 6d, f). Moreover, MAIT cells of HD patients displayed an effector memory phenotype (CD45RA-, CD62L-) and expressed more PD-1, indicative of increased activation. Importantly, upon in vitro restimulation, MAIT cells of HD patients secreted significantly more interleukin-17A (IL-17A) (Figure 6d, f).

In addition, we identified changes within a CD4+CD25+CD127- cell cluster (Cluster 3, Figure 6a-c), indicating alterations in Treg subpopulations. Total Treg proportions were not altered between HC and HD (Supplementary Figure 6b). However, since different subpopulations with partly different functions are known to exist within the total Treg population, we extended the Treg characterization (Supplementary table 1, T surface and T activation) ${ }^{14}$. Adjusted for multiple testing, several Treg subpopulations, characterized by activation markers and chemokine receptors, were significantly changed in HD patients (Figure 6e). In detail, Treg from HD patients with a central-memory phenotype (CD45RA-, CD62L+) showed a higher 
medRxiv preprint doi: https://doi.org/10.1101/2022.01.21.22269663; this version posted January 23, 2022. The copyright holder for this preprint (which was not certified by peer review) is the author/funder, who has granted medRxiv a license to display the preprint in perpetuity. All rights reserved. No reuse allowed without permission.

267 expression of PD-1 indicating activation state. Based on the expression of chemokine 268 receptors, Th1-like (CXCR3+), Th17-like (CXCR3-CCR6+CCR4+CCR10-) and Th22-like 269 (CXCR3-CCR6+CCR4+CCR10+) Treg were significantly diminished in HD patients 270 compared to HC (Figure 6e, g). Taken together, we observed significant alterations in T cell 271 subtypes, namely MAIT cells and Treg, which play an important role in mucosal immunity 272 and inflammation. 
medRxiv preprint doi: https://doi.org/10.1101/2022.01.21.22269663; this version posted January 23, 2022. The copyright holder for this preprint (which was not certified by peer review) is the author/funder, who has granted medRxiv a license to display the preprint in perpetuity.

All rights reserved. No reuse allowed without permission.

\section{Discussion}

274 Inflammation is a hallmark of CKD, detectable even at young age and particularly prognosis-

275 determining. We show in children with CKD, that intestinal barrier dysfunction and dysbiosis

276 are associated with a systemic bacterial metabolite imbalance that contributes to the pro-

277 inflammatory phenotype of several immune cells including monocytes and T cells. We also

278 provide novel insight into the microbiota-immune crosstalk mediated by TRP metabolites and

279 SCFA in CKD. Thus, we demonstrate a stage-dependent aberration of the microbiome-

280 immune axis, which is both a contributor to inflammation and a potential target for anti-

281 inflammatory therapeutic strategies.

282 The young cohort enrolled for this study exhibits a markedly increased risk for cardiovascular

283 disease, indicated by a high prevalence of arterial hypertension despite antihypertensive treatment as well as clear evidence of systemic inflammation (TNF-a). Inflammation is considered to be a main driver of cardiovascular disease in $C K D^{15}$. Early cardiovascular pathologies and complications in children with CKD have been described previously ${ }^{16,17}$, the burden of which accumulates with age and causes a fatal increase of CKD-associated mortality ${ }^{1}$. This is remarkable given that CKD occurs in children in the virtual absence of diseases that can cause both CKD and CVD, such as diabetes and metabolic syndrome. This is particularly relevant for the present study, as traditional comorbidities in adults represent additional influences on microbiota-immune interaction. Therefore, it can be assumed that the microbiome and immune signatures presented here are influenced to a smaller degree by traditional comorbidities and represent specific signatures of CKD.

For the first time, we demonstrate that children with CKD already exhibit considerable stagedependent intestinal barrier dysfunction indicated by increased serum levels of Zo-1 and sCD14. Zo-1 regulates intestinal permeability ${ }^{18}$ and has been associated with impaired barrier function in various conditions such as obesity, diabetes ${ }^{19}$ and autoimmune diseases ${ }^{20}$. Impaired barrier function permits the translocation of luminal LPS into the circulation. Consequently, we detected a CKD stage dependent increase in serum levels of the LPS 
medRxiv preprint doi: https://doi.org/10.1101/2022.01.21.22269663; this version posted January 23, 2022. The copyright holder for this preprint (which was not certified by peer review) is the author/funder, who has granted medRxiv a license to display the preprint in perpetuity.

All rights reserved. No reuse allowed without permission.

300

301

302

303

304

305

306

307

308

309

310

311

312

313

314

315

316

317

318

319

320

321

322

323

324

325

326

binding protein SCD14, suggesting LPS-induced inflammation ${ }^{21-23}$. Elevated serum levels of sCD14 have been associated with an increased risk of CVD in two independent cohort studies $^{24,25}$. Intestinal barrier dysfunction develops along with or as a consequence of dysbiosis, presumably as a consequence of a dysbalance of microbial metabolites, such as SCFA $^{26,27}$. Therefore, we analyzed the composition of the gut microbiome in our cohort. In line with studies of adult CKD patients ${ }^{5,7,28,29}$, we observed CKD stage-dependent compositional changes. This microbial signature was most dominantly present in patients with HD displaying an increase of proteolytic bacteria such as Citrobacter (Enterobacteriaceae) and a decrease of saccharolytic bacteria such as Bifidobacterium (Bifidobacteriaceae), Fusicatenibacter (Lachnospiraceae) and Subdoligranulum (Ruminococcaceae). Since adults, unlike children, may well exhibit a variety of comorbidities whose presence can have an additional obscuring influence on the microbiome (e.g. diabetes $^{30}$, obesity ${ }^{31}$, and fatty liver disease ${ }^{32}$ ), it can be assumed that the data presented here are less influenced by such comorbidities and therefore appear to be more clearly CKDassociated.

The enrichment of Enterobacteriaceae found in HD patients affects the microbial metabolism of nutrients as they express tryptophanases that metabolize TRP to indoles ${ }^{29}$. Dietary TRP is metabolized both by somatic cells and by the intestinal microbiota to metabolites with various functions ${ }^{33,34}$. We found that TRP metabolites in the blood of CKD patients increased in a stage-dependent manner, which was predominantly driven by the disproportional increase of metabolites of bacterial origin. Therefore, dysbiosis and intestinal barrier dysfunction, as present in CKD and HD patients in our cohort, are likely contributing to the accumulation of uremic solutes ${ }^{35}$ in addition to their reduced renal elimination ${ }^{29,36}$.

In our cohort, microbially-derived IXS and ILA as well as host-derived KYN, 3HK, KA, XA and AA were significantly elevated in CKD and HD patients, while serum levels of TRP were reduced. Both indole and KYN derivates are ligands of the AhR, thereby influencing innate and adaptive immune responses ${ }^{10,33,34}$. Consequently, the AhR activation potential of serum 
medRxiv preprint doi: https://doi.org/10.1101/2022.01.21.22269663; this version posted January 23, 2022. The copyright holder for this preprint (which was not certified by peer review) is the author/funder, who has granted medRxiv a license to display the preprint in perpetuity.

All rights reserved. No reuse allowed without permission.

327 from our HD patients was increased, confirming previous findings in adults ${ }^{37}$. Of note, the 328 degradation of TRP to KYN metabolites is regulated by tryptophan 2,3-dioxygenase in the 329 liver, which is upregulated by chronic inflammation ${ }^{38}$ and influenced by diabetes ${ }^{39-41}$ and obesity $^{42}$. In contrast to previous studies ${ }^{39-41}$, our study emphasizes enhanced TRP metabolism and AhR activation in CKD irrespective of traditional comorbidities.

Myeloid cells are known to be modulated by the AhR and are thus particularly affected by uremic TRP metabolites ${ }^{10,33,34}$. As indicated by unsupervised clustering and confirmed by hierarchical gating we demonstrated a pathological shift from classical towards intermediate and non-classical monocytes in HD patients. This monocyte signature has previously been associated with an increased risk of $C V D^{43,44}$. Most notably, we showed that isolated monocytes exhibited a higher production of TNF-a after incubation with serum from patients treated by $\mathrm{HD}$ compared to $\mathrm{HC}$, which was dependent on AhR function. Thus, the increased TNF- $\alpha$ concentrations in the circulation are at least partly a consequence of the effect of the increased and mainly microbially produced TRP metabolites on the AhR of monocytes, and possibly also other immune cells.

In line with the depletion of SCFA-generating saccharolytic bacteria ${ }^{45}$, such as Bifidobacterium, Fusicatenibacter and Subdoligranulum in CKD and HD patients, we show lower systemic levels of the SCFA propionate. There is a growing body of evidence about the pivotal role of SCFA in local gut homeostasis and the protection from CVD in vitro ${ }^{46}$ and in vivo ${ }^{47}$. Since SCFA are known to enhance the abundance and suppressive function of Treg cells in mice ${ }^{48}$ and humans ${ }^{49}$, we analyzed T cells by multi-color flow cytometry. Based on 348 the expression of chemokine receptors ${ }^{14,50}$, we found a decrease of Th1-like, Th17-like and Th22-like Treg in HD patients. The lower frequencies of these Treg subtypes might be explained by both, lower peripheral induction as a consequence of reduced availability of SCFA $^{48}$ and increased recruitment of Treg to sides of inflammation, e.g. atherosclerotic plaques $^{51}$. Moreover, the frequency of dysfunctional Treg with a central memory phenotype expressing PD-1 was elevated in HD patients. Circulating Treg expressing PD-1 are known 
medRxiv preprint doi: https://doi.org/10.1101/2022.01.21.22269663; this version posted January 23, 2022. The copyright holder for this preprint (which was not certified by peer review) is the author/funder, who has granted medRxiv a license to display the preprint in perpetuity.

All rights reserved. No reuse allowed without permission.

354 to exhibit reduced suppressive function and molecular signatures of exhaustion ${ }^{52}$. In light of 355 the recognized importance of chronic inflammation for CVD development, the diminished 356 anti-inflammatory function as a consequence of reduced abundances of Treg subtypes and 357 increased abundances of dysfunctional, exhausted Treg is likely to play a role in CVD 358 development ${ }^{50,51}$. Interestingly, our unsupervised FlowSOM analysis clearly indicated that circulating MAIT cells were reduced in HD patients, expressed markers of exhaustion (PD-1) and produced higher amounts of IL-17A. This pattern has been described for several autoimmune, inflammatory and cardiometabolic disease ${ }^{53}$, such as obesity and type two diabetes ${ }^{54}$. It is still a subject of discussion whether decreased MAIT cell abundances are mainly a consequence of migration to inflamed tissue or increased apoptosis ${ }^{53}$. In animal models, MAIT cells can promote inflammation and microbial dysbiosis leading to metabolic dysfunction during obesity ${ }^{53}$. A large cross-sectional analysis in patients with cardiometabolic diseases highlighted the positive association between decreased MAIT cell abundances and cardiovascular disease risk $^{55}$. A reduction of MAIT cell abundance has been described in CKD of predominantly diabetic cause, albeit without functional cytokine expression as shown here $^{56}$. Taken together, Treg and MAIT are two important cell populations phenotypically altered in HD patients that are known to be regulated by the microbiota, further emphasizing the importance of the microbiota-immune axis in CKD.

Noteworthy, patients after KT still showed significantly elevated serum levels of TNF- $\alpha$ compared to $\mathrm{HC}$, albeit lower than in $\mathrm{CKD}$ and $\mathrm{HD}$. There were no differences in serum markers of intestinal barrier function and only slight alterations in the microbiota composition, although the limited size of our cohort is less suited to detect fine-scaled differences between HC and KT. While microbial SCFA and indole metabolism apparently recovers after KT, serum levels of $\mathrm{KYN}$ and $3 \mathrm{HK}$ were still elevated. In contrast, adult patients after $\mathrm{KT}$ exhibited a significant decrease in alpha diversity and an increase of Proteobacteria, which is in part driven by the use of immunosuppressive drugs ${ }^{57}$. In a murine kidney transplantation 
medRxiv preprint doi: https://doi.org/10.1101/2022.01.21.22269663; this version posted January 23, 2022. The copyright holder for this preprint

(which was not certified by peer review) is the author/funder, who has granted medRxiv a license to display the preprint in perpetuity.

All rights reserved. No reuse allowed without permission.

381 model, mice after allograft transplantation exhibited dysbiosis even in the absence of

382 antibiotics and immunosuppression ${ }^{58}$. As gut dysbiosis and impaired microbial production of

383 SCFA seem to play a role in allograft rejection as well ${ }^{58}$, the absence of dysbiosis in children

384 after KT might attribute to a more favorable transplant outcome in children compared to 385 adults.

386 In conclusion, the present study is the first to show CKD stage-dependent alterations of the

387 microbiota-metabolite-immune axis in children with CKD in the absence of comorbidities

388 seen in adult patients. Our data demonstrate alterations at all levels of this pivotal axis. In

389 this context, TRP metabolites act as a mechanistic link between the microbiota and the

390 immune system, contributing to a pro-inflammatory phenotype in an AhR-dependent manner

391 - even at a young age. SCFA deficiency may further exacerbate CKD-associated chronic

392 inflammation and intestinal barrier dysfunction. These data provide strong evidence that the

393 microbiota is an important stimulus for persistent inflammation. Restoring intestinal eubiosis

394 could favorably influence the pro-inflammatory sequelae. Therefore, the microbiota appears

395 a promising target of future therapeutic strategies aimed at sustained containment of

396 inflammation to prevent chronic sequelae such as CVD and premature mortality in CKD. 
medRxiv preprint doi: https://doi.org/10.1101/2022.01.21.22269663; this version posted January 23, 2022. The copyright holder for this preprint (which was not certified by peer review) is the author/funder, who has granted medRxiv a license to display the preprint in perpetuity.

All rights reserved. No reuse allowed without permission.

397

398

399

400

401

402

403

404

405

406

407

408

409

410

411

\section{Acknowledgments}

This work was supported by local resources of the participating institutions. JH was supported by the Peter-Stiftung für die Nierenwissenschaft. JH, MW, SKF, and UL were supported by the German Center for Cardiovascular Research (DZHK), partner site Berlin. UL was supported by the German Federal Ministry of Education and Research (EMBARK; 01KI1909B) under the frame of JPI AMR (EMBARK; JPIAMR2019-109). S.G. was supported by the Bundesministerium für Bildung und Forschung funding MSTARS (Multimodal Clinical Mass Spectrometry to Target Treatment Resistance). F.B. was supported by the Berlin Institute of Health BIH-MD-TRENAL stipend. NW was supported by the European Research Council (ERC) under the European Union's Horizon 2020 research and innovation program (852796) and by a grant from the Corona-Stiftung in the German Stifterverband. NW and SKF were supported by the Deutsche Forschungsgemeinschaft (German Research Foundation, SFB 1365 and SFB 1470). The sponsors had no involvement in study design, data collection, analysis and interpretation of data and in the decision to submit this article for publication.

The authors thank Gudrun Koch, Jana Czychi, Gabriele N'diaye and Kerstin Sommer for their technical assistance and Nadine Unterwalder for her kind support in analyzing serum cytokine levels.

\section{Author contributions}

J.H., N.W. and D.M. led and conceived the project. J.H. and H.B. designed and performed most experiments, analyzed and interpreted the data. J.H., S.K., D.E. and L.D.K. conducted patient recruitment under supervision of D.M.. U.L., T.U.P.B., H.A. and S.K.F. performed the statistical analyses and data integration. J.H., H.B., M.I.W. and A.M. performed and analyzed flow cytometry. V.MP. performed most of the in vitro experiments. A.T. and O.D. performed $16 S$ sequencing. D.L.V., M.K., S.G., S.K. and J.A.K. performed metabolite analysis. P.B., 
medRxiv preprint doi: https://doi.org/10.1101/2022.01.21.22269663; this version posted January 23, 2022. The copyright holder for this preprint (which was not certified by peer review) is the author/funder, who has granted medRxiv a license to display the preprint in perpetuity. All rights reserved. No reuse allowed without permission.

423 K.U.E., N.W., and D.M. helped with data interpretation. N.W. supervised the experiments and 424 data analysis. J.H., H.B. and N.W. wrote the manuscript with key editing by F.B., U.Q. and 425 K.U.E. and further input from all authors.

426

427 Competing interest: None declared.

428

429 Data availability

430 All data produced in the present study are available upon reasonable request to the authors. 


\section{$431 \quad$ Figures}

a

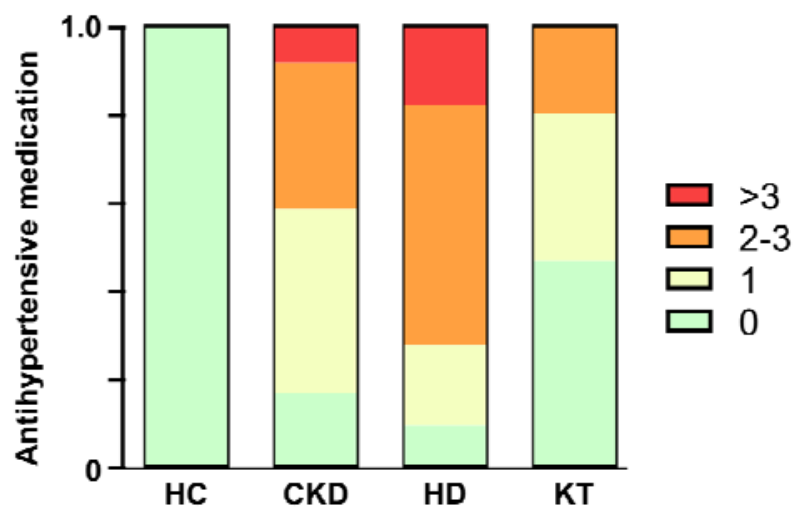

C

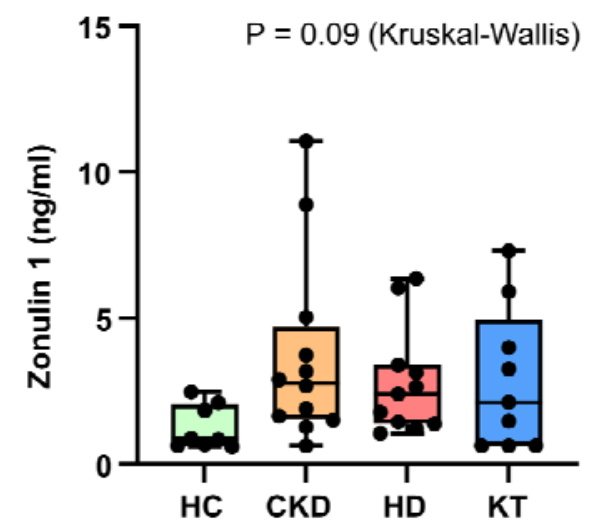

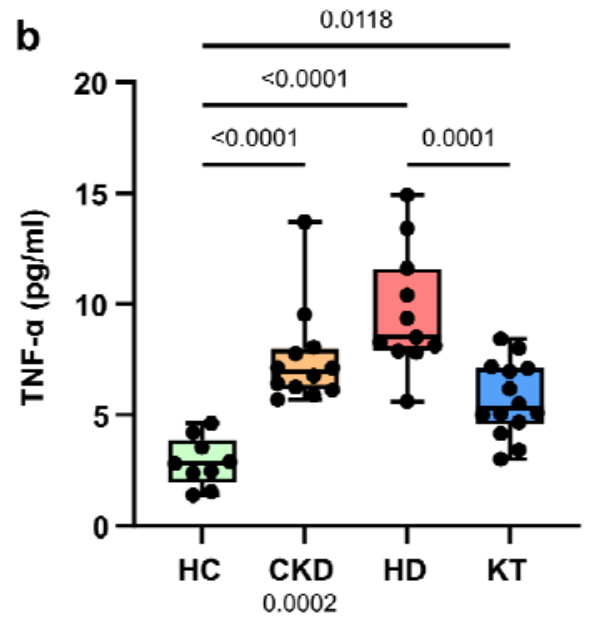

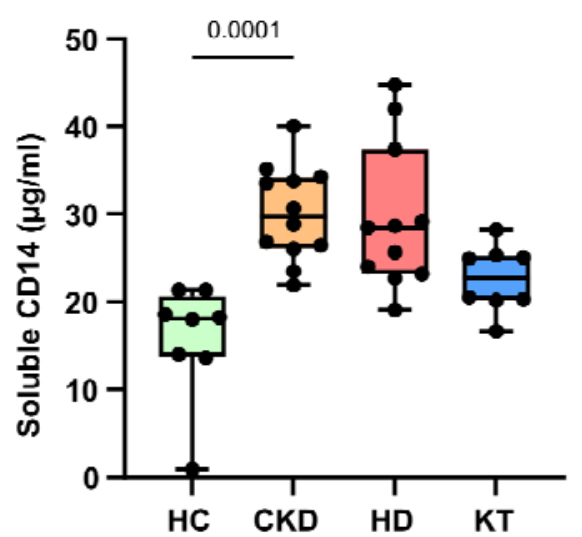

432

433

434

435

436

437

438

439

440

441

442

Figure 1: Arterial hypertension and systemic inflammation are linked to impaired intestinal barrier function in pediatric chronic kidney disease. The number of antihypertensive drugs per individual ( $\mathrm{a}, \mathrm{n}=48$ patients) is shown in patients with chronic kidney disease (CKD G3-4), hemodialysis (HD), after kidney transplantation (KT) and healthy controls ( $\mathrm{HC}$ ). Plasma TNF-a (b, $\mathrm{n}=46$ patients) was analyzed by chemiluminescence immunoassay. Gut barrier function was assessed using Zonulin 1 and soluble CD14 (c, n=40 patients) ELISA measurements in plasma. Data is shown as a box (median and interquartile range) and whiskers (min-max) with overlaid dot plot. $P$ values $\leq 0.05$ are shown, as measured by ordinary one-way ANOVA or Kruskal-Wallis test followed by Tukey's or Dunn's post-hoc correction for multiple comparisons, as appropriate. 

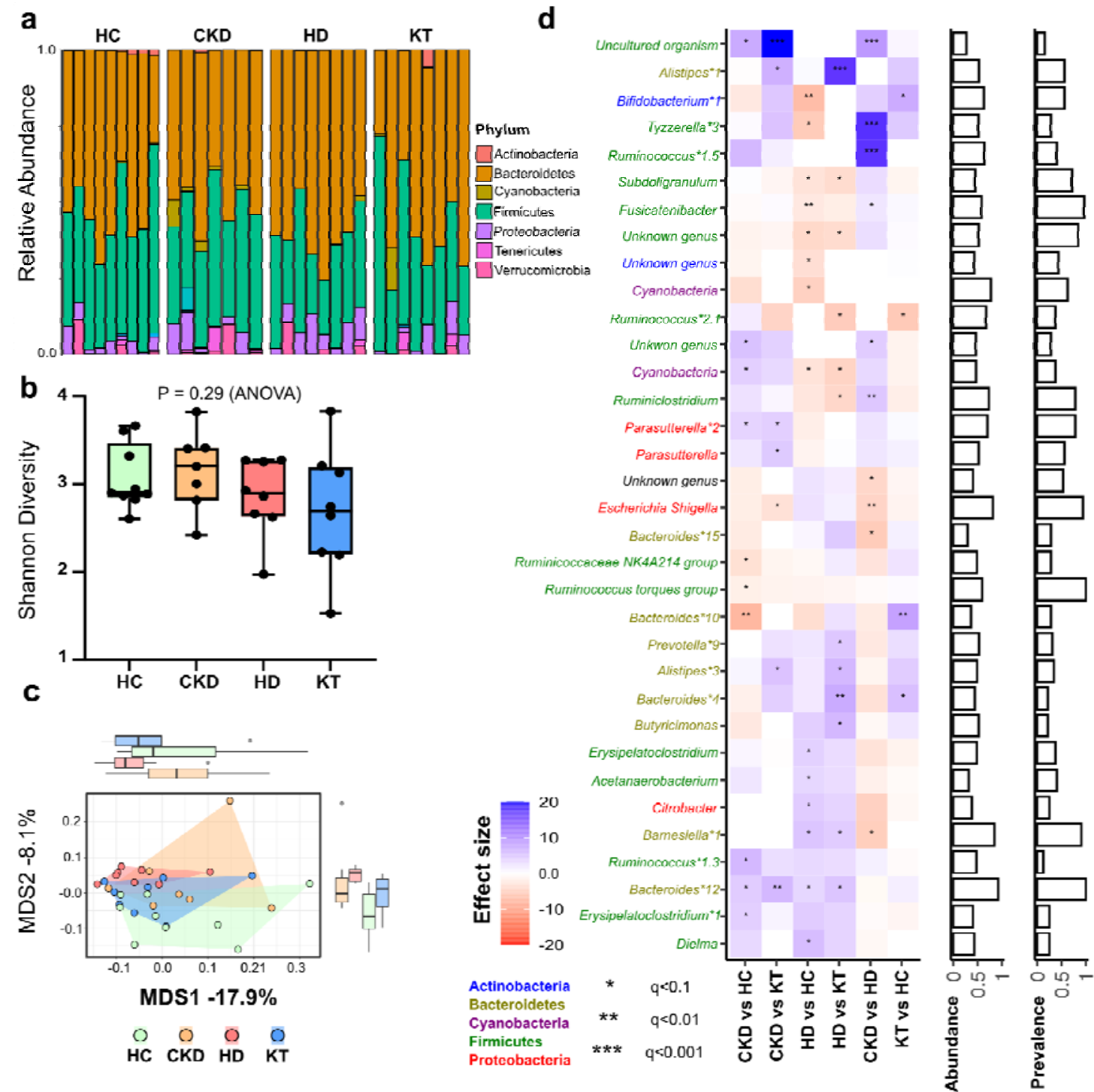

444

Figure 2: Characteristics of gut microbiota in a cohort of pediatric patients with chronic kidney disease compared to healthy controls. Analysis of gut microbiota from 16S rRNA sequencing in children $(n=32)$ with chronic kidney disease (CKD G3-4), patients with hemodialysis (HD), patients after kidney transplantation (KT) and healthy controls $(\mathrm{HC})$. a) Relative abundance on phylum level of individuals according to their respective group. b) Alpha diversity as measured by Shannon diversity. Data is shown as a box (median and interquartile range) and whiskers (min-max) with overlaid dot plot. c) Beta diversity assessment by Principal Coordinate Analysis (PCoA) based on Canberra distance $(p=0.01$ by PERMANOVA). d) Analyses of group differences on genus level are shown as a heatmap. Patient groups were tested against each other (pairwise). The heatmap shows significant 
medRxiv preprint doi: https://doi.org/10.1101/2022.01.21.22269663; this version posted January 23, 2022. The copyright holder for this preprint

(which was not certified by peer review) is the author/funder, who has granted medRxiv a license to display the preprint in perpetuity.

All rights reserved. No reuse allowed without permission.

455 changes in abundance using DESeq2 v1.30.1 package. Multiple groups of the same genus

456 reported by Lotus due to lacking coverage in available phylogenetic databases are marked

457 by numbers. Bar charts (right) show abundance and prevalence; abundance is calculated as

$458 \log ($ genus count)/log(max(genus count)); prevalence for each genus is calculated across the

459 whole data set. All significance estimates were adjusted for multiple tests using Benjamini-

460 Hochberg FDR correction. 
a

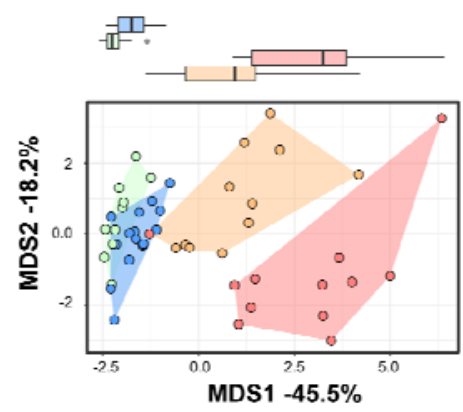

$\begin{array}{cccc}0 & 0 & 0 & 0 \\ H C & \text { CKD } & \text { HD } & \text { KT }\end{array}$

c

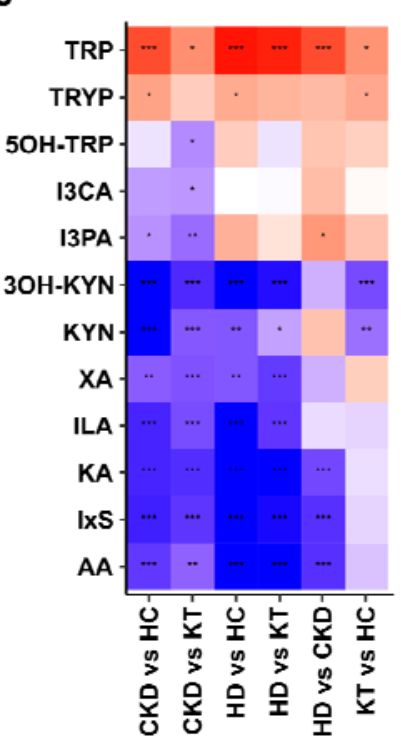

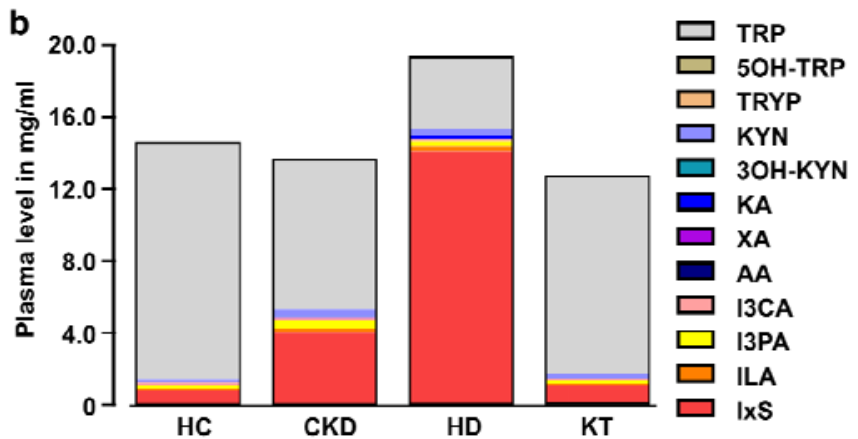

d
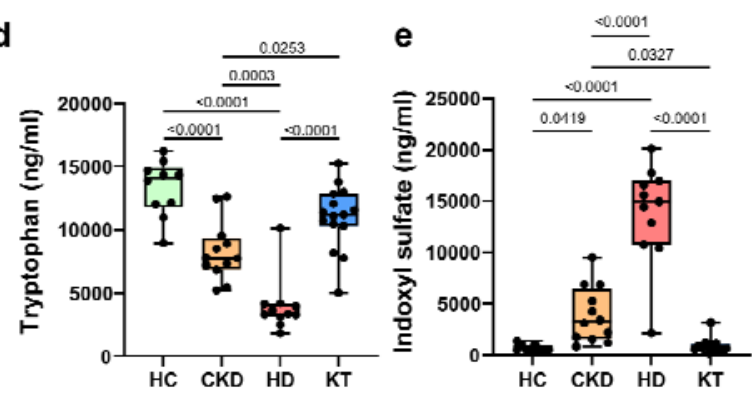

461

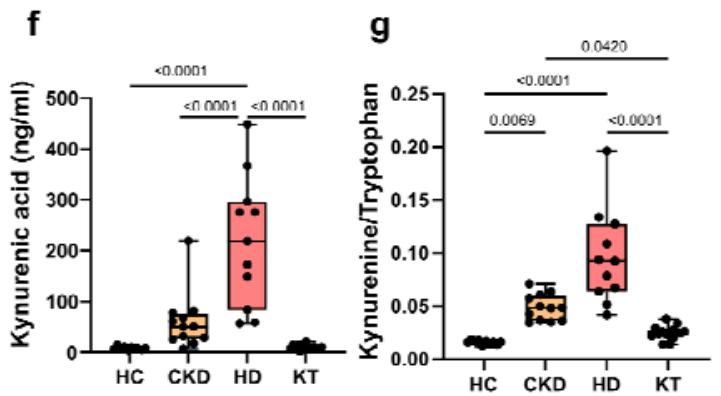

h

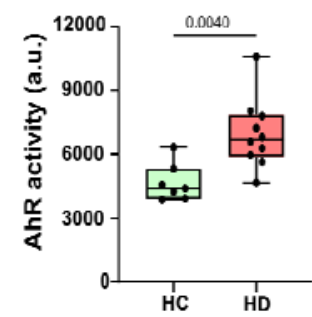

Figure 3: Stage-dependent activation of plasma tryptophan metabolism activates the

Aryl-hydrocarbon receptor. Tryptophan (TRP) and its metabolites were measured in

plasma of children at different stages of chronic kidney disease (CKD) compared to healthy controls $(n=48)$. a) Multivariate analysis (Principal Coordinate Analysis) of all measured metabolites discriminates between patients with CKD G3-4, patients with hemodialysis (HD), patients after kidney transplantation (KT) and healthy controls (HC). b) Cumulative load of TRP and its metabolites. c) Univariate analysis depicted as heatmap shows effect sizes (Cliff's delta) for each pair of patient groups. Colours denote the effect directions (bluepositive and red-negative) and magnitudes (the darker the colour, the stronger the magnitude); asterisks represent the association significance. Statistical significance was assessed by Mann-Whitney U-test and Benjamini-Hochberg false discovery rate correction. 
medRxiv preprint doi: https://doi.org/10.1101/2022.01.21.22269663; this version posted January 23, 2022. The copyright holder for this preprint

(which was not certified by peer review) is the author/funder, who has granted medRxiv a license to display the preprint in perpetuity.

All rights reserved. No reuse allowed without permission.

473 Group differences of TRP (d), indoxyl sulfate (IxS, e) and kynurenin acid (KA, f) were further

474 visualized in box plots. The Kynurenine/Tryptophan ratio (g) indicates the activity of

475 tryptophan degradation to kynurenine metabolites. The activity of the Aryl-hydrocarbon

476 receptor $(\mathrm{AhR}, \mathrm{h})$ was analyzed using a transfected reporter cell line after 48 hrs incubation

477 with serum of $\mathrm{HC}(\mathrm{n}=7)$ and $\mathrm{HD}(\mathrm{n}=10)$ patients. $P$ values $\leq 0.05$ are shown, as measured by

478 ordinary one-way ANOVA or Kruskal-Wallis test and adjusted by post-hoc Tukey's or Dunn's

479 correction for multiple testing $(\mathrm{d}-\mathrm{g})$ or by $\mathrm{t}$ test $(\mathrm{h})$. Data is shown as a box (median and

480 interquartile range) and whiskers (min-max) with overlaid dot plot.

481 Abbreviations: $\mathrm{TRP}=$ tryptophan, $5 \mathrm{OH}-\mathrm{TRP}=5$-hydroxy-tryptophan, $\mathrm{TRYP}=$ tryptamin, $\mathrm{KYN}=$

482 kynurenine, $3 \mathrm{OH}-\mathrm{KYN}=3$-hydroxy-kynurenine, $\mathrm{KA}=$ kynurenic acid, $\mathrm{AA}=$ anthranilic acid,

$483 \mathrm{XA}=$ xanthurenic acid, IXS= indoxyl sulfate; I3CA = indole-3-carboxyaldehyde, I3PA = indole-

484 3-propionic acid, ILA= indole lactate, $\mathrm{AhR}=$ aryl hydrocarbon receptor. 

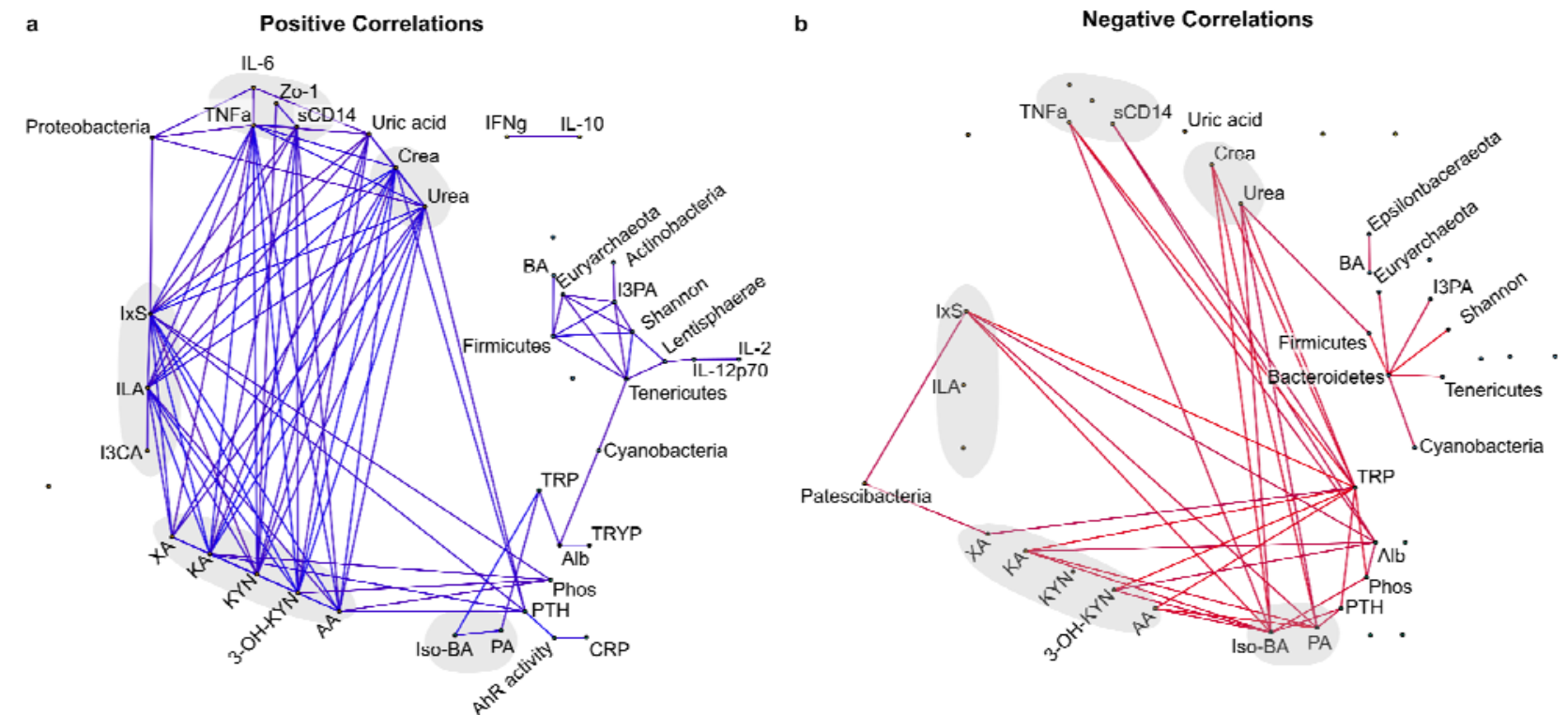

486 Figure 4: Correlation network of gut microbiome, clinical parameters, plasma

tryptophan metabolites and cytokines. Laboratory parameters, tryptophan metabolites (

$488=48)$, cytokines $(n=46)$ and taxonomic data $(n=32)$ were associated using pairwise

489 Spearman correlations and adjusted for multiple testing using the Benjamini-Hochberg FDR

490 correction. Edges for which absolute rho $>0.3$ and $Q<0.1$ are visualized. For better

491 visualization eGFR was removed as creatinine and urea convey similar information. a)

492 Positive correlations. b) Negative correlations.

493 Abbreviations: $\mathrm{TRYP}=$ tryptamin, $\mathrm{TRP}=$ tryptophan, $\mathrm{KYN}=$ kynurenine, $\mathrm{KA}=$ kynurenic acid,

$4943 \mathrm{OH}-\mathrm{KYN}=3$-hydroxy-kynurenine, $\mathrm{AA}=$ anthranilic acid, $\mathrm{XA}=$ xanthurenic acid, $\mathrm{PA}=$ propionic

495 acid, $B A=$ butyric acid, Iso-BA= isobutyric acid, Zo-1= zonulin-1, sCD14= soluble CD14, IxS=

496 indoxyl sulfate, ILA = indole lactate, I3CA = indole-3-carboxyaldehyde, I3PA = indole-3-

497 propionic acid, $\mathrm{CrP}=\mathrm{C}$-reactive protein. $\mathrm{Crea}=$ creatinine, $\mathrm{phos}=$ phosphate, $\mathrm{Alb}=$ albumin. 


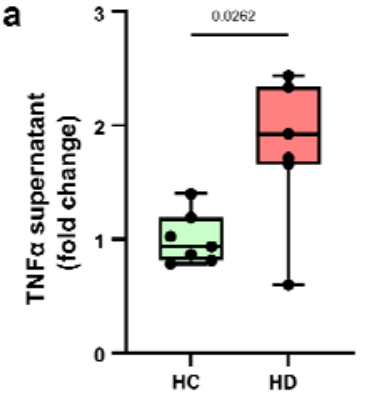

b

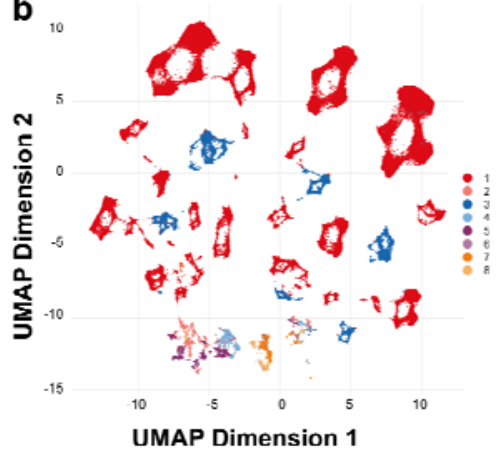

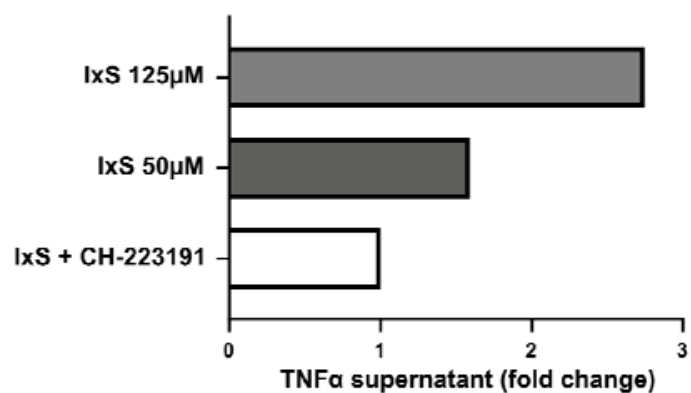

C
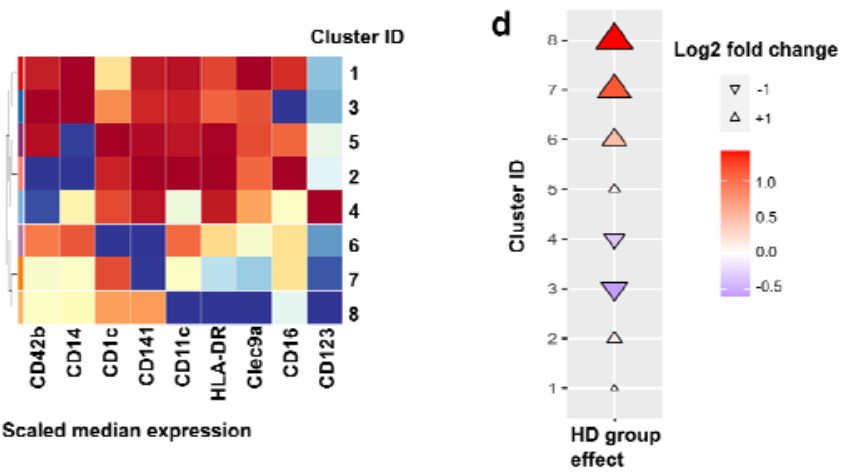

498
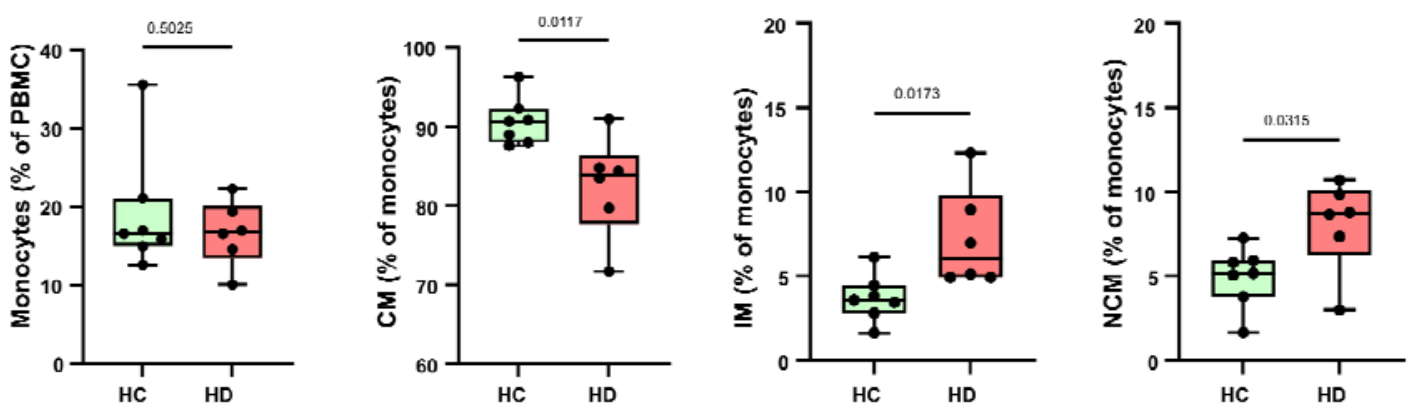

Figure 5: Monocyte subtypes promote inflammation in chronic kidney disease.

500

501

502

503

504

505

506

507

508

509

Monocytes isolated from healthy donors were incubated with serum from hemodialysis patients $(H D, n=7)$ and healthy controls $(H C, n=7)$. Monocytes were incubated with indoxyl sulfate (IXS) in presence or absence of the AhR antagonist $\mathrm{CH}-223191$. TNF-a was measured in the culture supernatant after $24 \mathrm{hrs}$ incubation using ELISA (a). Peripheral blood mononuclear cells (PBMC) were isolated from HD $(n=6)$ and $\mathrm{HC}(n=7)$ individuals for surface staining and multi-color flow cytometry was performed. Unsupervised clustering by FlowSOM revealed 8 different cell clusters (b) characterized by the differential expression of 9 surface marker describing myeloid and dendritic cells (c). Cuneiform plots depict the log2fold changes for these clusters between $\mathrm{HD}$ and $\mathrm{HC}$ (indicated by color, size and directionality of the triangles, d). Classical hierarchical gating of total monocytes, classical 
medRxiv preprint doi: https://doi.org/10.1101/2022.01.21.22269663; this version posted January 23, 2022. The copyright holder for this preprint

(which was not certified by peer review) is the author/funder, who has granted medRxiv a license to display the preprint in perpetuity.

All rights reserved. No reuse allowed without permission.

510 monocytes (CD16+), non-classical (CD14+), and intermediate (CD14+CD16+) monocytes is

511 shown in e).

512 Abbreviations: $\mathrm{AhR}=$ aryl hydrocarbon receptor. 


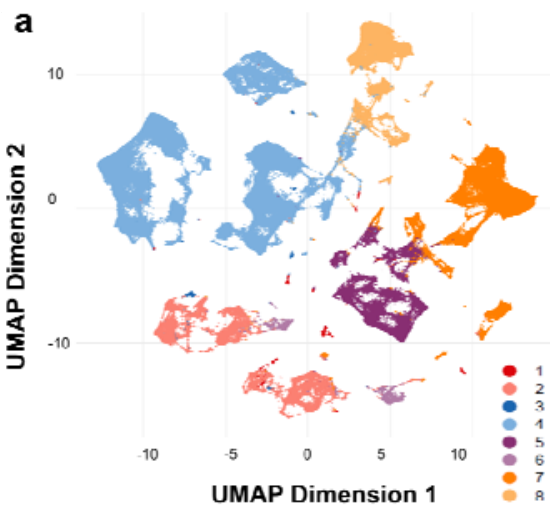

d

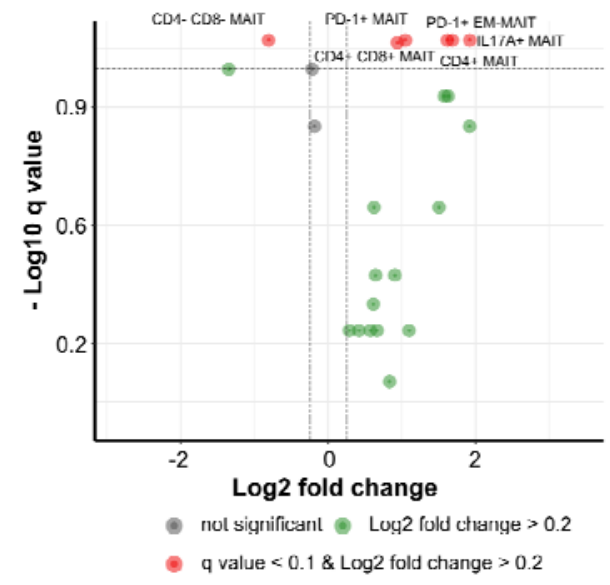

f
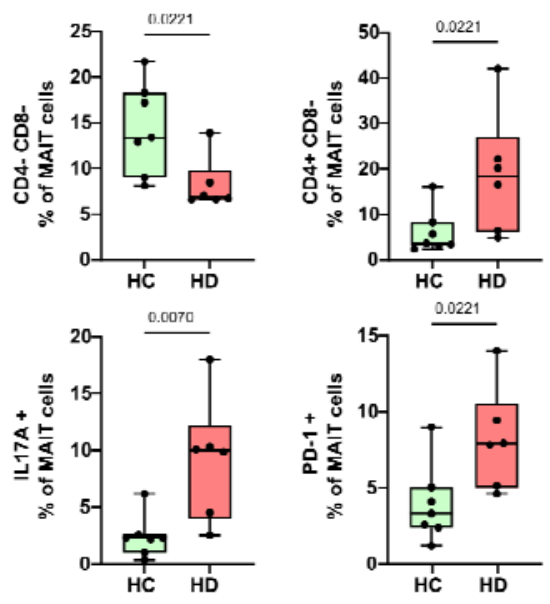

b

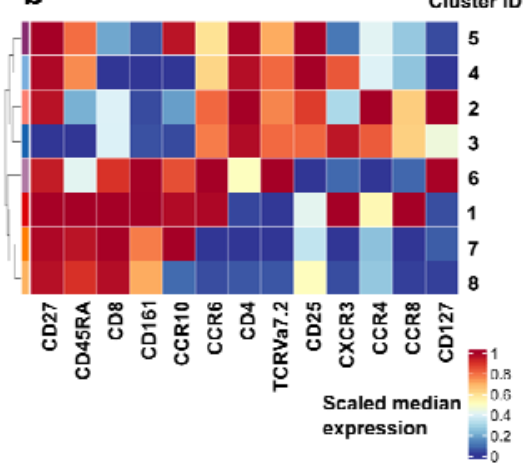

c

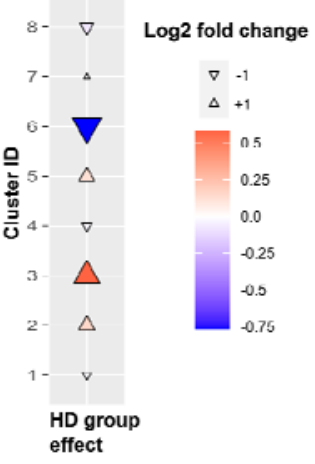

e

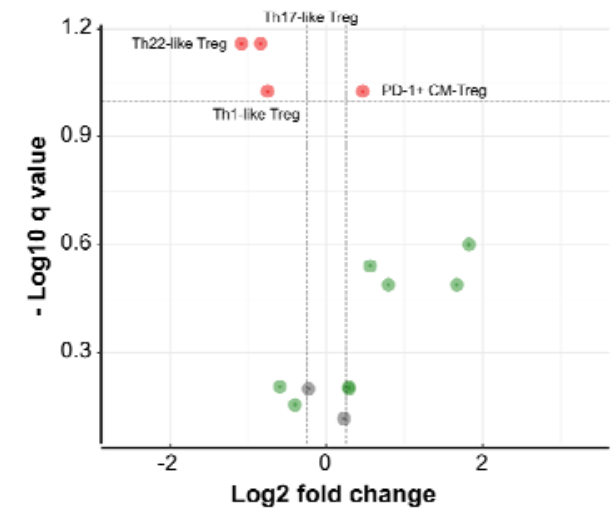

- nul significant - Lug̣2 fold change $>0.2$

- $\mathrm{q}$ value $<0.1 \& \log 2$ fold change $>0.2$

g
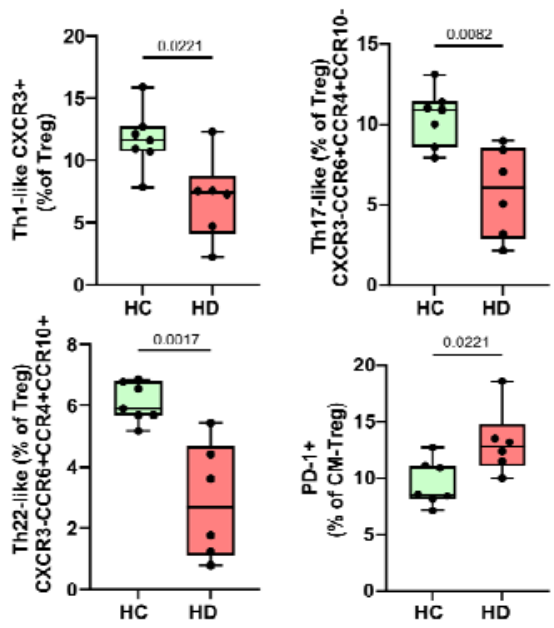

Figure 6: Pro-inflammatory T cell subtypes in chronic kidney disease. Unsupervised

515 clustering of $\mathrm{HD}(\mathrm{n}=6)$ and $\mathrm{HC}(\mathrm{n}=7)$ individuals by FlowSOM revealed 8 T cell clusters (a)

516 based on the differential expression of surface marker (b). c) Cuneiform plots showing the

517 log2-fold changes for these clusters between HD and HC (indicated by color, size and

518 directionality of the triangles). Volcano plot of MAIT (d) and Treg (e) subpopulations by

519 hierarchical gating. y-axis indicates $Q$ value by Mann-Whitney U-test and Benjamini- 
medRxiv preprint doi: https://doi.org/10.1101/2022.01.21.22269663; this version posted January 23, 2022. The copyright holder for this preprint

(which was not certified by peer review) is the author/funder, who has granted medRxiv a license to display the preprint in perpetuity.

All rights reserved. No reuse allowed without permission.

520 Hochberg false discovery rate correction, x-axis log2-fold change between HD and HC.

521 Significantly altered subpopulations are depicted as box (median and interquartile range) and

522 whiskers (min-max) with overlaid dot plots for MAIT and Treg in $\mathrm{f}$ ) and $g$ ), respectively. For $f$

523 and $\mathrm{g}, P$ values $\leq 0.05$ are shown, as measured by $\mathrm{t}$ test or Mann-Whitney- $U$ test as

524 appropriate.

525 Abbreviations: MAIT = mucosa-associated invariant $\mathrm{T}$ cells; Treg= regulatory $\mathrm{T}$ cells, $\mathrm{HD}=$ 526 hemodialysis, $\mathrm{HC}=$ healthy controls. 
medRxiv preprint doi: https://doi.org/10.1101/2022.01.21.22269663; this version posted January 23, 2022. The copyright holder for this preprint (which was not certified by peer review) is the author/funder, who has granted medRxiv a license to display the preprint in perpetuity.

Tables

528 Table 1: Patients baseline characteristics. Patients $(n=48)$ were grouped into four

529 categories $(\mathrm{CKD}=$ chronic kidney disease, $\mathrm{HD}=$ hemodialysis, $\mathrm{KT}=$ kidney transplantation,

$530 \mathrm{HC}=$ healthy controls). Data is shown as mean \pm standard deviation or percentage (\%) as

531 appropriate.

\begin{tabular}{|c|c|c|c|c|}
\hline & $\mathrm{HC}$ & CKD G3-G4 & HD & KT \\
\hline Patients (n) & 10 & 12 & 11 & 15 \\
\hline Age (years) & $12.1 \pm 4.2$ & $8.3 \pm 2.3$ & $13.6 \pm 3.2$ & $9.1 \pm 2.9$ \\
\hline Female & $7(70 \%)$ & $5(42 \%)$ & $3(27 \%)$ & $6(40 \%)$ \\
\hline \multicolumn{5}{|l|}{ Diagnosis } \\
\hline CAKUT & $N / A$ & $5(42 \%)$ & $5(45 \%)$ & $8(53 \%)$ \\
\hline Tubulointerstitial & $N / A$ & $2(17 \%)$ & $1(9 \%)$ & $3(20 \%)$ \\
\hline Glomerulopathy & $N / A$ & $4(33 \%)$ & $4(36 \%)$ & $3(20 \%)$ \\
\hline Post-AKI & $N / A$ & $1(8 \%)$ & $1(9 \%)$ & $1(7 \%)$ \\
\hline Healthy & $10(100 \%)$ & $N / A$ & $N / A$ & $N / A$ \\
\hline Caucasian & $9(90 \%)$ & $12(100 \%)$ & $3(27 \%)$ & $11(73 \%)$ \\
\hline Weight (percentile) & $61 \pm 23$ & $38 \pm 21$ & $8 \pm 7$ & $52 \pm 28$ \\
\hline BMI (percentile) & $57 \pm 21$ & $35 \pm 19$ & $31 \pm 19$ & $59 \pm 25$ \\
\hline eGFR $\left(\mathrm{ml} / \mathrm{min} / 1.73 \mathrm{~m}^{2}\right)$ & $100.2 \pm 29.3$ & $29.6 \pm 14.6$ & $6.6 \pm 1.1$ & $78.6 \pm 19.4$ \\
\hline Urea (mg/dl) & $30 \pm 7$ & $112 \pm 67$ & $147 \pm 39$ & $36 \pm 14$ \\
\hline Uric acid (mg/dl) & $4.8 \pm 1.3$ & $7.6 \pm 2.2$ & $6.7 \pm 1.2$ & $5.4 \pm 1.4$ \\
\hline Phosphate (mmol/l) & $1.3 \pm 0.1$ & $1.6 \pm 0.3$ & $2.0 \pm 0.5$ & $1.5 \pm 0.3$ \\
\hline Albumin (g/l) & $47.7 \pm 5.3$ & $43.8 \pm 13.0$ & $38.0 \pm 4.8$ & $40.0 \pm 3.4$ \\
\hline CrP (mg/l) & $2.6 \pm 5.9$ & $0.7 \pm 1.1$ & $3.6 \pm 6.9$ & $2.0 \pm 1.8$ \\
\hline PTH (pmol/l) & $\mathrm{N} / \mathrm{A}$ & 13.2. \pm 8.5 & $38.5 \pm 38.4$ & $7.7 \pm 3.8$ \\
\hline Triglycerides (mg/dl) & $N / A$ & $166 \pm 75$ & $186 \pm 54$ & $112 \pm 57$ \\
\hline Antihypertensive treatment & $0(0 \%)$ & $10(83 \%)$ & $10(91 \%)$ & $8(53 \%)$ \\
\hline Antihypertensive drugs (n) & 0 & $1.8 \pm 1.5$ & $2.4 \pm 1.9$ & $0.8 \pm 0.9$ \\
\hline $\begin{array}{l}\text { Arterial Hypertension } \\
\text { (BP }>95^{\text {th }} \text { Percentile) }\end{array}$ & $N / A$ & $2(17 \%)$ & $6(55 \%)$ & $5(33 \%)$ \\
\hline
\end{tabular}
applicable. 
medRxiv preprint doi: https://doi.org/10.1101/2022.01.21.22269663; this version posted January 23, 2022. The copyright holder for this preprint (which was not certified by peer review) is the author/funder, who has granted medRxiv a license to display the preprint in perpetuity.

All rights reserved. No reuse allowed without permission.

\section{References}

5361 Gansevoort, R. T. et al. Chronic kidney disease and cardiovascular risk: epidemiology,

537 mechanisms, and prevention. Lancet 382, 339-352, doi:10.1016/S0140-6736(13)60595-4 (2013).

2 Claro, L. M. et al. The Impact of Uremic Toxicity Induced Inflammatory Response on the Cardiovascular Burden in Chronic Kidney Disease. Toxins (Basel) 10, doi:10.3390/toxins10100384 (2018).

Onal, E. M., Afsar, B., Covic, A., Vaziri, N. D. \& Kanbay, M. Gut microbiota and inflammation in chronic kidney disease and their roles in the development of cardiovascular disease.

Hypertens Res 42, 123-140, doi:10.1038/s41440-018-0144-z (2019).

4 Vanholder, R., Schepers, E., Pletinck, A., Nagler, E. V. \& Glorieux, G. The uremic toxicity of indoxyl sulfate and p-cresyl sulfate: a systematic review. J Am Soc Nephrol 25, 1897-1907, doi:10.1681/ASN.2013101062 (2014).

$5 \quad$ Vaziri, N. D. et al. Chronic kidney disease alters intestinal microbial flora. Kidney Int 83, 308315, doi:10.1038/ki.2012.345 (2013).

6 Ramezani, A. et al. Role of the Gut Microbiome in Uremia: A Potential Therapeutic Target. Am J Kidney Dis 67, 483-498, doi:10.1053/j.ajkd.2015.09.027 (2016).

7 Wang, X. et al. Aberrant gut microbiota alters host metabolome and impacts renal failure in humans and rodents. Gut 69, 2131-2142, doi:10.1136/gutjnl-2019-319766 (2020).

8 Holle, J. et al. Indoxyl sulfate associates with cardiovascular phenotype in children with chronic kidney disease. Pediatr Nephrol, doi:10.1007/s00467-019-04331-6 (2019).

9 Harambat, J., van Stralen, K. J., Kim, J. J. \& Tizard, E. J. Epidemiology of chronic kidney disease in children. Pediatr Nephrol 27, 363-373, doi:10.1007/s00467-011-1939-1 (2012).

10 Rothhammer, V. \& Quintana, F. J. The aryl hydrocarbon receptor: an environmental sensor integrating immune responses in health and disease. Nat Rev Immunol 19, 184-197, doi:10.1038/s41577-019-0125-8 (2019).

11 Quintelier, K. et al. Analyzing high-dimensional cytometry data using FlowSOM. Nat Protoc 16, 3775-3801, doi:10.1038/s41596-021-00550-0 (2021).

12 Abeles, R. D. et al. CD14, CD16 and HLA-DR reliably identifies human monocytes and their subsets in the context of pathologically reduced HLA-DR expression by CD14(hi)/CD16(neg) monocytes: Expansion of CD14(hi)/CD16(pos) and contraction of CD14(lo) /CD16 (pos) monocytes in acute liver failure. Cytometry A 81, 823-834, doi:10.1002/cyto.a.22104 (2012).

13 Wong, K. L. et al. Gene expression profiling reveals the defining features of the classical, intermediate, and nonclassical human monocyte subsets. Blood 118, e16-31, doi:10.1182/blood-2010-12-326355 (2011).

14 Duhen, T., Duhen, R., Lanzavecchia, A., Sallusto, F. \& Campbell, D. J. Functionally distinct subsets of human FOXP3+ Treg cells that phenotypically mirror effector Th cells. Blood 119, 4430-4440, doi:10.1182/blood-2011-11-392324 (2012).

15 Jankowski, J., Floege, J., Fliser, D., Bohm, M. \& Marx, N. Cardiovascular Disease in Chronic Kidney Disease: Pathophysiological Insights and Therapeutic Options. Circulation 143, 11571172, doi:10.1161/CIRCULATIONAHA.120.050686 (2021).

16 Mitsnefes, M. M. Cardiovascular disease in children with chronic kidney disease. J Am SoC Nephrol 23, 578-585, doi:10.1681/ASN.2011111115 (2012).

17 Schaefer, F. et al. Cardiovascular Phenotypes in Children with CKD: The 4C Study. Clin J Am Soc Nephrol 12, 19-28, doi:10.2215/CJN.01090216 (2017).

18 Fasano, A. Zonulin and its regulation of intestinal barrier function: the biological door to inflammation, autoimmunity, and cancer. Physiol Rev 91, 151-175, doi:10.1152/physrev.00003.2008 (2011).

19 Yuan, J. H. et al. Impaired intestinal barrier function in type 2 diabetic patients measured by serum LPS, Zonulin, and IFABP. J Diabetes Complications 35, 107766, doi:10.1016/j.jdiacomp.2020.107766 (2021). 
58620 Tajik, N. et al. Targeting zonulin and intestinal epithelial barrier function to prevent onset of arthritis. Nat Commun 11, 1995, doi:10.1038/s41467-020-15831-7 (2020).

21 Schutt, C., Schilling, T., Grunwald, U., Schonfeld, W. \& Kruger, C. Endotoxin-neutralizing capacity of soluble CD14. Res Immunol 143, 71-78, doi:10.1016/0923-2494(92)80082-v (1992).

22 Poesen, R. et al. Associations of Soluble CD14 and Endotoxin with Mortality, Cardiovascular Disease, and Progression of Kidney Disease among Patients with CKD. Clin J Am Soc Nephrol 10, 1525-1533, doi:10.2215/CJN.03100315 (2015).

23 Zanoni, I. \& Granucci, F. Role of CD14 in host protection against infections and in metabolism regulation. Front Cell Infect Microbio/ 3, 32, doi:10.3389/fcimb.2013.00032 (2013).

24 Stanislawski, M. A. et al. Soluble CD14 Levels in the Jackson Heart Study: Associations With Cardiovascular Disease Risk and Genetic Variants. Arterioscler Thromb Vasc Biol 41, e369e378, doi:10.1161/ATVBAHA.121.316035 (2021).

25 Olson, N. C. et al. Soluble CD14, Ischemic Stroke, and Coronary Heart Disease Risk in a Prospective Study: The REGARDS Cohort. J Am Heart Assoc 9, e014241, doi:10.1161/JAHA.119.014241 (2020).

26 Hiippala, K. et al. The Potential of Gut Commensals in Reinforcing Intestinal Barrier Function and Alleviating Inflammation. Nutrients 10, doi:10.3390/nu10080988 (2018).

27 Geirnaert, A. et al. Butyrate-producing bacteria supplemented in vitro to Crohn's disease patient microbiota increased butyrate production and enhanced intestinal epithelial barrier integrity. Sci Rep 7, 11450, doi:10.1038/s41598-017-11734-8 (2017).

28 Hobby, G. P. et al. Chronic kidney disease and the gut microbiome. Am J Physiol Renal Physiol 316, F1211-F1217, doi:10.1152/ajprenal.00298.2018 (2019).

29 Gryp, T. et al. Isolation and Quantification of Uremic Toxin Precursor-Generating Gut Bacteria in Chronic Kidney Disease Patients. Int J Mol Sci 21, doi:10.3390/ijms21061986 (2020).

30 Forslund, K. et al. Disentangling type 2 diabetes and metformin treatment signatures in the human gut microbiota. Nature 528, 262-266, doi:10.1038/nature15766 (2015).

31 Bouter, K. E., van Raalte, D. H., Groen, A. K. \& Nieuwdorp, M. Role of the Gut Microbiome in the Pathogenesis of Obesity and Obesity-Related Metabolic Dysfunction. Gastroenterology 152, 1671-1678, doi:10.1053/j.gastro.2016.12.048 (2017).

32 Chu, H., Williams, B. \& Schnabl, B. Gut microbiota, fatty liver disease, and hepatocellular carcinoma. Liver Res 2, 43-51, doi:10.1016/j.livres.2017.11.005 (2018).

33 Roager, H. M. \& Licht, T. R. Microbial tryptophan catabolites in health and disease. Nat Commun 9, 3294, doi:10.1038/s41467-018-05470-4 (2018).

34 Dodd, D. et al. A gut bacterial pathway metabolizes aromatic amino acids into nine circulating metabolites. Nature 551, 648-652, doi:10.1038/nature24661 (2017). Vaziri, N. D., Yuan, J. \& Norris, K. Role of urea in intestinal barrier dysfunction and disruption of epithelial tight junction in chronic kidney disease. Am J Nephrol 37, 1-6, doi:10.1159/000345969 (2013).

36 Poesen, R. et al. Renal clearance and intestinal generation of $\mathrm{p}$-cresyl sulfate and indoxyl sulfate in CKD. Clin J Am Soc Nephrol 8, 1508-1514, doi:10.2215/CJN.00300113 (2013).

37 Dou, L. et al. Aryl hydrocarbon receptor is activated in patients and mice with chronic kidney disease. Kidney Int 93, 986-999, doi:10.1016/j.kint.2017.11.010 (2018).

38 Schefold, J. C. et al. Increased indoleamine 2,3-dioxygenase (IDO) activity and elevated serum levels of tryptophan catabolites in patients with chronic kidney disease: a possible link between chronic inflammation and uraemic symptoms. Nephrol Dial Transplant 24, 19011908, doi:10.1093/ndt/gfn739 (2009).

39 Mair, R. D., Sirich, T. L. \& Meyer, T. W. Uremic Toxin Clearance and Cardiovascular Toxicities. Toxins (Basel) 10, doi:10.3390/toxins10060226 (2018).

40 Debnath, S. et al. Tryptophan Metabolism in Patients With Chronic Kidney Disease Secondary to Type 2 Diabetes: Relationship to Inflammatory Markers. Int J Tryptophan Res 10, 1178646917694600, doi:10.1177/1178646917694600 (2017). 
$63841 \quad$ Pawlak, K., Kowalewska, A., Mysliwiec, M. \& Pawlak, D. Kynurenine and its metabolites-kynurenic acid and anthranilic acid are associated with soluble endothelial adhesion molecules and oxidative status in patients with chronic kidney disease. Am J Med Sci 338, 293-300, doi:10.1097/MAJ.0b013e3181aa30e6 (2009).

42 Cussotto, S. et al. Tryptophan Metabolic Pathways Are Altered in Obesity and Are Associated With Systemic Inflammation. Front Immunol 11, 557, doi:10.3389/fimmu.2020.00557 (2020).

43 Duni, A. et al. The Association of Circulating CD14++CD16+ Monocytes, Natural Killer Cells and Regulatory T Cells Subpopulations With Phenotypes of Cardiovascular Disease in a Cohort of Peritoneal Dialysis Patients. Front Med (Lausanne) 8, 724316, doi:10.3389/fmed.2021.724316 (2021).

44 Heine, G. H. et al. Monocyte subpopulations and cardiovascular risk in chronic kidney disease. Nat Rev Nephrol 8, 362-369, doi:10.1038/nrneph.2012.41 (2012).

45 Felizardo, R. J. F., Watanabe, I. K. M., Dardi, P., Rossoni, L. V. \& Camara, N. O. S. The interplay among gut microbiota, hypertension and kidney diseases: The role of short-chain fatty acids. Pharmacol Res 141, 366-377, doi:10.1016/j.phrs.2019.01.019 (2019).

46 Bartolomaeus, H. et al. Short-Chain Fatty Acid Propionate Protects From Hypertensive Cardiovascular Damage. Circulation 139, 1407-1421, doi:10.1161/CIRCULATIONAHA.118.036652 (2019).

47 Hsu, C. N., Lu, P. C., Hou, C. Y. \& Tain, Y. L. Blood Pressure Abnormalities Associated with Gut Microbiota-Derived Short Chain Fatty Acids in Children with Congenital Anomalies of the Kidney and Urinary Tract. J Clin Med 8, doi:10.3390/jcm8081090 (2019).

48 Arpaia, N. et al. Metabolites produced by commensal bacteria promote peripheral regulatory T-cell generation. Nature 504, 451-455, doi:10.1038/nature12726 (2013).

49 Haghikia, A. et al. Propionate attenuates atherosclerosis by immune-dependent regulation of intestinal cholesterol metabolism. Eur Heart J, doi:10.1093/eurheartj/ehab644 (2021).

50 Halim, L. et al. An Atlas of Human Regulatory T Helper-like Cells Reveals Features of Th2-like Tregs that Support a Tumorigenic Environment. Cell Rep 20, 757-770, doi:10.1016/j.celrep.2017.06.079 (2017).

51 Saigusa, R., Winkels, H. \& Ley, K. T cell subsets and functions in atherosclerosis. Nat Rev Cardiol 17, 387-401, doi:10.1038/s41569-020-0352-5 (2020).

52 Lowther, D. E. et al. PD-1 marks dysfunctional regulatory T cells in malignant gliomas. JCI Insight 1, doi:10.1172/jci. insight.85935 (2016).

53 Toubal, A. et al. Mucosal-associated invariant T cells promote inflammation and intestinal dysbiosis leading to metabolic dysfunction during obesity. Nat Commun 11, 3755, doi:10.1038/s41467-020-17307-0 (2020).

54 Magalhaes, l. et al. Mucosal-associated invariant T cell alterations in obese and type 2 diabetic patients. J Clin Invest 125, 1752-1762, doi:10.1172/JCI78941 (2015).

55 Touch, S. et al. Mucosal-associated invariant T (MAIT) cells are depleted and prone to apoptosis in cardiometabolic disorders. FASEB J, fj201800052RR, doi:10.1096/fj.201800052RR (2018).

56 Juno, J. A. et al. Mucosal-Associated Invariant T Cells Are Depleted and Exhibit Altered Chemokine Receptor Expression and Elevated Granulocyte Macrophage-Colony Stimulating Factor Production During End-Stage Renal Disease. Front Immunol 9, 1076, doi:10.3389/fimmu.2018.01076 (2018).

57 Swarte, J. C. et al. Characteristics and Dysbiosis of the Gut Microbiome in Renal Transplant Recipients. J Clin Med 9, doi:10.3390/jcm9020386 (2020).

58 Wu, H. et al. Gut Microbial Metabolites Induce Donor-Specific Tolerance of Kidney Allografts through Induction of T Regulatory Cells by Short-Chain Fatty Acids. J Am Soc Nephrol, doi:10.1681/ASN.2019080852 (2020). 